\title{
FEATURES CORRELATION CONSTITUTION AND STATE POLICY
}

\section{Bielov D. M., Vikhliaiev M. Yu.}

\section{INTRODUCTION}

Constitutionalism as a politico-legal category and doctrinal learning appears after the emergence and establishment of the constitution of the state in the modern sense of this term. It is inseparable and directly derived from the constitution of the state. Although not always the fact of the existence of a constitution automatically means the emergence of a particular model of constitutionalism. However, without the appearance (availability) of the constitution itself (in the broad sense of this notion), there is no need to talk about constitutionalism. The substantive basis, the very essence of constitutionalism, according to V. Shapoval, is expressed by the formula: "constitutional-legal norm + practice of its implementation", Therefore, a bit strange, in our opinion, when in certain writings, including monographs, there are such statements as "ancient”, "medieval”, "totalitarian" or "Soviet constitutionalism", since at that time the constitution as such (in the modern understanding of this concept) simply did not exist. However, it was precisely in previous times that, in fact, the foundations of the future phenomenon - constitutionalism were laid ${ }^{2}$.

The Constitution of Ukraine is a part of the national legal system, its core, acts as "coordinator of the system of legislation" 3 . But, as $\mathrm{Yu}$. Tykhomyrov notes, despite the fact that the Constitution, as if is in the middle of the legal array, its influence is not limited to the link "act-act". All elements of the legal system, in turn, also affect the constitution ${ }^{4}$.

On the one hand, the Constitution is a kind of construction, on which practically all legislation is being built ${ }^{5}$. It is the Constitution that defines the nature of the current legislation, the process of law-making - determines,

${ }^{1}$ В.М. Шаповал. Конституиійне право зарубіжних крайн: Підручник, АртЕк, Вища шк., Київ 1997, р. 135.

${ }^{2}$ П.Б. Стецюк. Основи теорії конституиії та конституціоналізму. Частина перша: Посібник для студентів, Астролябія, Львів 2004, р. 98.

${ }^{3}$ И.М. Степанов. Конституция и политика, Изд-во Наука, Москва 1984, р. 40.

${ }^{4}$ Ю.А.Тихомиров. И.В. Котелевская, Правовые акты. Учебно-практическое и справочное пособие, Юринформцентр, Москва 1999, р. 15.

${ }^{5}$ О.В. Оніщенко. Конституція України як основне джерело конституційного права України. Вид.: Консум, Київ 2005, р. 211. 
which basic acts are adopted by various bodies, their names, legal force, the process and procedure for the adoption of laws ${ }^{6}$. The development of legislation is possible only within the parameters enshrined in the Constitution, which serves as an important condition for ensuring its unity, internal coherence ${ }^{7}$. As S. Shevchuk notes, the constitutional norms are formulated in the form of an open text, and, consequently, constitute "empty vessels", which must be filled with a specific content ${ }^{8}$. Therefore, the adoption of a new constitution in the state, as a rule, causes significant changes and updates to current legislation. Ukraine is no exception. Although, as V. Opryshko notes, "the current legislation does not yet fit into the legal framework defined by the Constitution of Ukraine" " .

However, the notion of a constitution cannot be disclosed to the full extent without clarifying the question about not only its legal but also socio-political nature.

\section{Constitution and state policy: common questions}

Today, one of the reasons for the constant tension in relations between the supreme bodies of state power in Ukraine is the imperfection of the Basic Law, the different interpretation of its norms, as well as the fundamental change of the state policy, especially after the 2004-2005 presidential elections.

The constitution has a mixed political and legal nature, as well as to a large extent all constitutional law. Constitutional relations that arise on the basis of its provisions can also be characterized as having a dual nature: political and legal at the same time. Powerful relations subject to constitutional regulation create prerequisites for the appearance of political issues in constitutional law and politicize it to a certain extent. The political and legal in the constitution are closely intertwined, as well as the implementation of constitutional provisions can have a legal and political dimension.

As A. Heywood has rightly pointed out, for the vast majority of democratic states, constitutions were traditionally perceived as "precise descriptions of the current system of government"10. Consequently, any

${ }^{6}$ Е.И. Козлова, О.Е. Кутафин. Конституционное право России. Юристъ, Москва 2003, p. 87.

7 В.О. Лучин. Конституция Российской Федерации. Проблемы реализации, ЮнитиДана, Москва 2002, р. 79.

${ }^{8}$ С. Шевчук. Основи конституціийної юриспруденщії: Навч.посібник, Консум, Харків 2002, p. 7.

${ }_{9}^{9}$ В.Ф. Опришко. Конституиія України - основа системи національного законодавства. Видавничий Дім «Юридична книга», Київ, 2000, р. 118.

10 Э. Хейвуд. Политология. Юнити-Дана, Москва 2005, р. 359. 
constitution always carries a certain prognostic-axiological element, which allows foreseeing a further direction of the state development and, accordingly, state policy. It is important to note that the prognostic function of the Constitution is directly written by well-known domestic researcher Yu. Todyka ${ }^{11}$. However, we now mean not only one of the possible functions of the constitution but also the fact that at its level the values are laid down that the state is called to provide.

The authors of the monograph "Politics, Law and Power in the Context of Transformation Processes in Ukraine" characterize state policy as a "system of purposeful measures aimed at solving certain social problems, meeting public interests, ensuring the stability of the constitutional, economic, legal system of the country [...] the specificity of which is that it is realized through the power structures that have the authority of the monopoly right of the state to lawful coercion"12. Indeed, the link between the state policy and the constitution is shown by not only the reference to such a concept as "constitutional system". From the outset, the authors of the above-mentioned study establish a clear correlation between the direction of state policy and the process of ensuring social stability and satisfaction of the public interest. It should be borne in mind: the main social interests are always connected with the system of rights and freedoms of citizens of the state, which are not only formally fixed in the Constitution but must also be secured by it as a legal act of the highest legal force, which has a sign of direct imperative action (Article 8 of the Constitution of Ukraine) $)^{13}$.

The same can be said for a widely used in the modern Ukrainian science definition of the state policy by V. Tertychka. This author proposes to interpret the state policy in the following way: "relatively stable, organized, and purposeful activity/inactivity of state institutions, carried out by them directly or indirectly on a particular problem or a set of problems that affects the life of society"14. Moreover, justifying the appropriateness of this way of understanding the phenomenon of state policy, he notes that the definition of state policy implicitly implies that it is based on the law and must be legitimate. That is, state policy does not appear, so to speak, solely on its own accord and on their own will of those who are currently endowed with state power. On the contrary, in order that this direction of the state's activity

${ }^{11}$ Ю.Н. Тодыка. Конституция Украины, рр. 70-80.

12 Політика, право і влада в контексті трансформаційних процесів в Украйні. Еd. I.О. Кресіної. Інститут держави і права ім. В.М. Корецького НАН України, Київ 2006, р. 35.

${ }^{13}$ І. Гладуняк. Конституція, рр. 11-12.

${ }^{14}$ Політика, право і влада в контексті трансформаційних процесів в Україні, pp. 82-83. 
should be systematic and coherent, it is necessary from the very beginning to have a certain set of rules and principles that would indicate: a) the type of political regime; b) the way of organizing state power; c) the main political institutions, the presence of which ensures the normal development of the state mechanism; d) the basic values and tasks that must be implemented during state and social development.

These rules should be fixed at the legislative level so that there are no ambiguous political interpretations of the way, in which policy should be implemented and on what grounds ${ }^{15}$. The universal method of fixing these rules and regulations is the method of constitutional determination. By giving these rules and principles an imperative value, the state acts as the guarantor of the fact that all participants in social and political relations will adhere to them. At the same time, it itself, as a mechanism of institutionalized coercion, will act in accordance with certain standards. Therefore, it is quite natural that in all democratically-operated countries, programs for the realization of state policy are always developed and implemented in accordance with the constitution.

However, it is necessary to distinguish between the constitution as a legal act and the functions specific to it in the legal field and the constitution as a political document having a certain socio-political content that directly or indirectly affects the entire political system of the country ${ }^{16}$.

Consequently, the relationship between the constitution and politics manifests itself in two main areas. First, in a broad sense, political relations are one of the most important constituent parts of constitutional regulation. Constitutional norms set legal boundaries for the political process. They consolidate the foundations of the political system of society, and not only. In modern constitutions, the foundations of the social and spiritual systems of society, which affects the expansion of the object of constitutional regulation at the turn of XX - XXI centuries, are increasingly reflected. As rightly $\mathrm{V}$. Chyrkin notes, "constitutional law went beyond a largely formalized approach of the XVIII - XIX centuries and spread to the settlement of issues of the social system, the situation of one or another stratum, groups of the population (social, national, age, etc.), socio-economic rights"17.

Secondly, the constitution itself embodies a certain policy of the state, the desire of the project developers to consolidate certain principles and

${ }^{15}$ І. Гладуняк. Конституичія, рр. 11-12.

${ }^{16}$ Ibidem.

17 Б.Е. Чиркин. Об объекте конституционно-правового регулирования. Российский консти-туционализм: проблемь и решения: материаль международной конферениии, Академия, Москва 1999, р. 126. 
political values. Even K. Marx argued that "all legal has in its essence a political nature" ${ }^{18}$. This thesis on the Basic Law, according to V. Luchyn, becomes of a special significance. The political orientation of the constitution is one of the most important qualities that determine its special role in the legal system, a special social role in society. However, the idea that a constitution is created by the state to achieve a certain political goal requires some adjustments ${ }^{19}$.

From the standpoint of democratic constitutionalism and the theory of social contract, both the institutions of public authority and the electoral body participate in the act of constitution creation in one way or another. Therefore, official representatives of the state - only one of the subjects of the constitution creation. The constitution should integrate not only state goals of development but also the idea of society about the goals of social progress, to be an indicator of the needs of different social groups, the expression of their expectations and hopes ${ }^{20}$.

In the history of Ukrainian constitutionalism, the Constitution has repeatedly acted as a tool of state policy, ruling circles or political forces that came to power. Thus, the First Soviet Constitution - the Constitution of the RSFSR of 1918 - consolidated the victory of the proletariat and the poorest peasantry after the October Revolution, and was actively used by the Bolsheviks as a means of political struggle against social strata and classes that did not share the ideals of socialist construction.

Interesting is the characteristic of the Constitution of the RSFSR of 1918, given by the well-known Soviet legal ideologist of the 20's P. Stuchka to the twelfth anniversary of the revolution of the state and law. He called it "the civil war constitution", which is largely justified since it openly supported class positions on the issue of the acquisition and implementation of basic civil and political rights and freedoms ${ }^{21}$. Later in the process of constitutional development of the Soviet state, constitutional right gradually cleared itself from the ability to act as a tool of class domination, acquiring the nature of a universal legal regulator ${ }^{22}$.

In the mid-80's, political scientist I. Stepanov, reflecting on the relationship between the constitution and politics, expressed the view that politics and law should be represented in the constitution in an organically

${ }^{18}$ К. Маркс, Ф. Энгельс. Сочинения, 2-е изд. vol. I, Политиздат, Москва 1991, p. 635.

${ }_{19}$ В.О. Лучин. Конституционные нормы и правоотночения: учебное пособие [для вузов], Эксмо, Москва 1997, pp. 33-34.

${ }^{20}$ І. Гладуняк. Конституція, рр. 11-12.

${ }^{21}$ П.И. Стучка. Двенадцать лет револющии государства и права, “Революция права” 6 (1929), p. 10.

${ }^{22}$ І. Гладуняк. Конститучиiя, рр. 11-12. 
integral form, "balanced in a coherent unity"23. Of course, during the Soviet period, the study of the constitutional policy was limited by many partyideological barriers. However, the search for an optimal combination of politics and law in the constitution, constitutional policy, and political law is an important and constantly restored process of democratic development.

On the one hand, the tradition of observing constitutional limitations by subjects of political activity and political relations should be developed. On the other hand, the constitutional law should not be disconnected from political issues, and constitutionalists should seek to see political aspects in the implementation of constitutional norms. The study of political issues in constitutional law can shed light on the motives for adopting the constitution as a whole or individual constitutional changes, it can serve as an explanation or justification for the constitutionally regulated actions of state bodies and officials. In general, political issues highlight the controversial and problem areas of constitutional and legal development, contribute to the formation of a constitutional paradigm within the legally established normative framework of relations of person, society, and state ${ }^{24}$.

In the concept of a political constitution, a special vision of a political community is laid down, in which a coordinated interaction between citizens and authorities is ensured and a political agreement on rules of conduct in the political sphere is taking place. History gives a lot of examples of violent imposing of the constitution by the ruling party, the authoritarian head of state, the oligarchic or military regime. However, in the spirit of the democratic policy, a constitution as a political document cannot be a political pact, which reflects the search for public consent and compromise in resolving various political and social conflicts ${ }^{25}$.

In the political sphere, functions of the constitution are inextricably linked with its nature. In many respects, its effectiveness in the field of politics depends on the nature of the constitution. After all, the nature of the constitution is its socio-political content. In the national political science, in the Soviet era, the class nature of the constitution and its content were distinguished. Under class nature, they understood the basic socio-political characteristics of the constitution. It finds its manifestation in its content, principles, properties, and functions, has a decisive influence on its form, defining its fundamental features. The content of the

${ }^{23}$ И.М. Степанов. Конституцчия и политика, р. 24.

${ }^{24}$ И.А. Кравец. Сущฺность конституций и конституционный процесс (динамика сочиально-политического содержания российских конституций). «Весник Московского» гос. ун-та. 4 (2003), р. 35.

${ }_{25}$ І. Гладуняк. Конституичія, pp. 11-12. 
constitution is the specification of its class nature. Moreover, the content may vary within a specific nature under the influence of a number of objective and subjective factors. The constitution had a dual meaning social and legal ${ }^{26}$. The point is that this approach was based on a formative theory, according to which the specifics of the nature of the constitution in different countries were tied to a certain socio-economic formation. Throughout the period of the development of Soviet constitutions, even in the late period, known as "developed socialism", dominated the class concept of the nature of the constitution, which was determined by the class (classes) it serves and which type of property it establishes ${ }^{27}$.

In our opinion, the nature of the constitution derives from its sociopolitical content, so to speak, in a concentrated form. The legal content of the constitution is determined by the objects of constitutional regulation, in other words, what legal institutes, principles, and provisions are reflected in the text of the constitution and in this regard acquire the constitutional status. Given the differences in the legal and socio-political content of the constitution, it is necessary to identify the key elements of its nature, which have a political influence on the functioning of constitutional provisions.

These elements can be formulated in the form of theoretical postulates, the answers to which give a general idea of the nature of a specific constitution. These include:

1) the will of which political forces found a consolidation in constitutional provisions (whose political will was enshrined in the constitution?);

2) the interests of which social strata are reflected in the constitutional provisions and supported by them (whose interests are reflected and supported by the constitution?);

3) what is the degree of legitimacy of the constitution, which is largely determined by the terms of its project development and the procedure for its adoption (how the chosen procedure for the development and adoption of the constitution influenced the degree of its legitimacy?).

In specific historical conditions and the legal culture of an individual country, the answers to these questions may vary. In the constitutional history of one and the same country, different constitutions may have a

${ }^{26}$ Ю.Л. Юдин. Конституцчии, in: Конституционное право развивающчихся стран: предмет, наука, источники, еd. В.Е. Чиркин. Юридическая литература. Москва 1987, р. 39.

${ }_{27}$ Н.П. Фарберов. Новая Конституция СССР - манифест эпохи строительства коммунизма, in: Н.П. Фарберов. Конституция развитого социализма. Восход-А, Москва 1979, p. 68. 
different essence. Moreover, the essence of one and the same constitution can eventually be transformed and move away from the original idea of its creators. This is primarily related to the fact that the socio-political conditions of the constitution, the implementation of its provisions can change.

\section{Modern approaches to understanding the nature of the constitution}

In modern constitutionalism, there are three basic approaches to understanding the nature of the constitution: liberal-democratic, Marxist-Leninist, and theological. These three directions in constitutional law indicate differently the main purpose of the constitution in the political sphere.

The liberal-democratic approach was formed at the end of the XVIII century, although it relied on the ideas and values of the English and French educators, which were developed in the works of J. Locke, Ch. Montesquieu, J. Russo and others within the school of natural law.

At the heart of a liberal-democratic approach lies the doctrine of the social contract. According to it, the constitution is considered as the result of public consent, a compromise between different social strata and political forces on the fundamental principles of organization of society and state, the relationship between individuals and the state. The constitution as a social contract is an important indicator of the political consensus existing in society.

In countries where the constitution has long operated in a high political consensus, it becomes the nature of an agreement, to which each subsequent generation may add new provisions or change existing ones. According to the recognition of American constitutionalists N. Redlich, B. Schwartz, and J. Attanasio, in "American law, a word "constitution" has a more limited meaning; it is a written agreement transmitted from the first generation of Americans to future generations” ${ }^{\text {,2 }}$. Another American researcher J. Reiman argues that the foundations of American constitutional democracy are human rights and a social contract, and considers the constitution from three sides: as a written text, as a social practice, and as a moral promise ${ }^{29}$.

The Marxist-Leninist approach was developed in the second half of the XIX - the beginning of the XX century. As a theoretical concept, it was formed on the ideas and views expressed by the classics of Marxism (K. Marx and F. Engels) and substantially complemented by the leader of

\footnotetext{
${ }^{28}$ N. Redlich, B. Schwartz, J. Attanasio, Understanding Constitutional Law, Matthew Bender, Irwin 1995, p. 21.

${ }^{29}$ J. Reiman. The Constitution, Rights, the Conditions of Legitimacy, in: Constitutionalism: The Philosophical Dimension, ed. A.S. Rosenbaum, Greenwood Press, New York 1988, p. 133.
} 
the Bolsheviks V. Lenin. It sought to adapt the postulates of classical Marxism to the socio-political realities of early XX century. K. Marx and F. Engels noted that the constitution, as a result of the class struggle, is established by the ruling class, the class that won. In their opinion, after the seizure of power, the ruling classes must constitution their power not only in the form of state but also "to give their will ... a general expression in the form of state will, in the form of law" ${ }^{30}$. And such a law, above all, is a constitution. Stressing the class nature of the constitution, V. Lenin wrote: "The nature of the constitution is that the basic laws of the state in general and the laws concerning the electoral law to representative institutions, their competence, etc., express the true balance of forces in the class struggle" 31 .

The practical implementation of this approach was first introduced during the creation of the first Soviet Constitution of the RSFSR in 1918, and then became widely used in socialist states, where a special type of constitution and one or another type of Soviet form of government were established. The representatives of this approach saw in the constitution not the result of the agreement but the outcome of the class struggle, which was recognized as the dominant engine of historical progress. A class approach to understanding the nature of the constitution denied the right to a political compromise. The constitution always manifests the will of the economically dominant class, which has won a political victory over other classes and smaller social groups. Therefore, the constitution may reflect interests of only the winner of the political struggle, a class that has occupied economic heights, that is, such a class should also possess means of production ${ }^{32}$.

The theological approach is a definite combination of ideas of secular and divine law. It appeared much later than other approaches as a result of distribution in the XX century (mainly in its second half) of constitutional ideas and principles in the countries of the Arab East, where the sources of Muslim law occupy a dominant position. The notion of a constitution in these countries is associated with the provision of divine rules of conduct for a "religious community". If a constitution exists as a written act, it should not contradict the most important source of Muslim law - the Quran. Political struggle is not encouraged, if not forbidden, and

${ }^{30}$ К. Маркс, Ф. Энгельс. Сочинения, р. 122.

${ }^{31}$ В.И. Ленин. Полное собрание сочинений. Vol. XXXVI, Политиздат, Москва 1980, p. 535.

32 Д.М. Бєлов. Структура та зміст конституиії: окремі аспекти, «Науковий вісник Ужгородського національного університету. Серія Право»,14 (1) 2010, р. 85. 
consent is achieved through faithfulness to the confession of a single religion of Islam.

The norms and principles of Muslim law have a profound impact on the constitutional legislation and the form of government in countries such as Iran and Saudi Arabia. Muslim law also plays a leading role in these countries in other areas of current law, which is confirmed at the constitutional level. For example, the Iranian Constitution establishes the provisions on the mandatory compliance of all laws that are adopted with the Sharia law ${ }^{33}$. Moreover, the Sharia regulations are transformed into legal constructs, which are used in the theory and practice. Thus, the three requirements of the Quran, which obliged to consult in making important decisions, to handle all cases in all fairness, and obey the ruler, were the basis of the theory of "Islamic rule" developed by Muslim legal scientists in detail - theories of the organization and activities of the state ${ }^{34}$.

The constitution in these countries legitimises "Islamic rule" as a special form of theocratic state ${ }^{35}$. By revealing the content of the Islamic Republic, the Iranian Constitution states that it is based on the belief in Allah and its comprehensive power, "divine revelation" that determines any laws, as well as in the belief in the responsibility of man to Allah (Article 2). With the role of Islam, as the most important political and ideological basis of the state, the relation to it as one of the legitimizing factors ensuring the stability of the ruling regime is connected. Therefore, it is not a constitution that acts as a measure of "legitimacy" of the existing regime but the Islamic values that arise from Sharia and are firmly rooted in the mass consciousness.

Interesting, in our opinion, is the approach of Hungarian constitutionalist A. Sajó. Rejecting traditional views on the nature of the emergence of constitutions (an ideal program of reconstruction of society, ensuring stability, rational state structure), he formulates a paradoxical thesis: constitutions arise under the influence of fear. Like a psychoanalyst who studies human experiences during the formation of his biography, he sees a direct motive for the adoption of constitutions in the dominant fears of authors of constitutions ${ }^{36}$.

33 Л.Р. Сюкияйнен. Мусульманское право: вопросы теории и практики. Наука, Москва 1986, p. 102.

${ }^{34}$ Idem. Шариат и мусульманско-правовая культура, Армада, Москва 1997, pp. 14-15.

${ }^{35}$ Е.Н. Салыгин. Теократическое государство. Юридическая литература, Москва 1999, p. 45.

${ }^{36}$ A. Sajó. Limiting Government. An Introduction to Constitutionalism, Central European University Press, Budapest 1999, p. 311. 
Thus, the founding fathers of the US Constitution in 1787 acted under the influence of a paranoid desire to avoid the establishment of a monarchy or popular democracy; an example of the ineffectiveness of the Weimar Constitution and the establishment of the Nazi regime hung over the authors of the German Constitution of 1949; the Constitution of France of De Gaulle of 1958 sought to prevent the repetition of parliamentary paralysis of the Fourth Republic.

The constitutions adopted during the democratic revolutions in the countries of Eastern Europe (Hungary, Slovakia, Czech Republic, Bulgaria), sought to overcome the preliminary system of power concentration in the hands of one person. Emphasizing the principle of national sovereignty, they put forward an idea of a strong unicameral parliament, which inevitably leads to the consolidation of government ${ }^{37}$.

\section{The legal nature of the constitution of Ukraine}

In the Ukrainian society, which is at the stage of modernization of its political, legal, and economic systems, the attitude to the Constitution is a private aspect of the social outlook split by the differentiation of social strata. This attitude reflects the process of a new stratification of the changing society. Constitutional development of Ukraine in the XX century was accompanied by several fundamental changes in the civilizational foundations of the existence of society and the state. Existing constitutions reflected in a different way the balance of political forces and had unequal socio-political content ${ }^{38}$.

The Constitution of 1919 reflected and embodied the political development of revolutionary authoritarianism. Its essence lies in the fact that, in general, it is based on a broad democratic basis, in contrast to the census monarchical constitutions of the XIX - the beginning of the XX century. The logic of revolutionary authoritarianism came from the principle of Salus populi suprema lex est (from Latin "The good of the people should be the supreme law").

The constitution consolidated the new political reality of the union of workers and peasants for the growth of the people's good. V. Lenin stressed that the Soviet constitution is not invented by any commission, not written off from other constitutions, not drawn up in the offices, but developed on the basis of the experience of the struggle of the working people and the organization of proletarian masses ${ }^{39}$. However, the concern for the people's

\footnotetext{
${ }^{37}$ Ibidem. P. 312.

38 Д.М. Бєлов. Структура та зміст конституиії, р. 86.

${ }^{39}$ В.И. Ленин., Полное собрание сочинений, р. 45.
} 
good was given to the revolutionary avant-garde - the Communist Party, whose representatives, combining party and state posts, used authoritarian methods of domination. The class approach to the constitution served as a justification for the use of violence against social strata that did not share the goal of a revolutionary transition to a socialist society ${ }^{40}$.

The logic of revolutionary authoritarianism, as rightly noted by A. Galkin and $\mathrm{Yu}$. Krasin, had deep internal contradictions ${ }^{41}$. The fact is that people consist of individuals and social groups that have different interests, hopes, convictions. The constitution can integrate and allow coexistence of all these social strata only with the relatively free regulation of the legal and political space. Otherwise, the authoritarian power of the revolutionaries, pretending to be the role of the speaker of the will of the people and the common good, inevitably evolves until the domination of the political minority, which imposes their will on all the citizens.

Consequently, the Constitution of 1919 performed not the function of a limitation of state power, in contrast to the liberal constitutions of the late XVIII century, but the function of justification of political power, not limited by law and justice, such as based on revolutionary legitimacy and expediency $^{42}$.

The political significance of proletariat dictatorship has survived in subsequent constitutions adopted after the formation of the USSR. The provisions on the dictatorship of the proletariat existed in the Constitutions of the USSR of 1929 and 1937. In the process of political evolution, the social basis of the proletariat dictatorship gradually expanded. First, the social strata that emerge as a result of the freedom of economic activity, which was prohibited in the Soviet state, were eliminated. Secondly, through the system of local councils, ordinary people were involved in the state control under the political control of the ruling party of the Bolsheviks. Thirdly, the social policy of the Soviet state contributed to the growth of the welfare of Soviet citizens, although the Communist Party remained the main interpreter of what was considered as "common good". One can agree that the dictatorship of the proletariat was "intended to enlighten the masses, drawing them into the practical work of building a new society, and then giving way to a people's power" ${ }^{\text {" }}$. The strategic goal of transforming the dictatorship of the proletariat into a regime of

${ }^{40}$ Д.М. Бєлов. Структура та зміст конституиії, р. 86.

${ }^{41}$ А.А. Галкин, Ю.А. Красин. Россия на перепутье: авторитаризм и демократия: варианты развития, Юридическая литература, Москва 1995, р. 23.

42 Д.М. Бєлов. Структура та зміст конституиії, р. 87.

43 Е.А. Лукьянова. Значение Конституции СССР 1977 2. в развитии источников российского государственного права. «Государство и право». 4 (2001), р. 22. 
democracy has influenced the development of the concept of the selfgovernment of the working people, which envisaged a widespread and wide replacement of forms of government by forms of public self-government.

After the death of J. Stalin and the condemnation of a person's cult during the reign of $\mathrm{M}$. Khrushchev, the doctrine of a nation-state that was embodied in the norms of the Constitution of 1978 began to form. This doctrine included several elements that reflected both continuity with the former doctrine of the dictatorship of the proletariat and the novelty of understanding the social activity of the state and tasks of political development.

The doctrine of the state of the whole people was intended to show the destruction of class contradictions within the Soviet society, which was based, as argued by the official ideology, on the alliance of workers, peasants, and intellectuals. A political alliance of two classes and a stratum (the intelligentsia, in the Marxist sense, could not be a class by definition) testified that the Soviet constitution had reached its highest level of development and had the widest possible social base. The absence of social strata capable of expressing disagreement or opposing the constitution created the appearance of general agreement and political approval of the social and legal order.

Expansion of political participation of Soviet citizens through the system of councils was accompanied by the preservation of political monism of the party - the state. Some weakening of the principle of political monism consisted in the fact that non-party citizens began to be admitted to public positions, and in the elections, with the preservation of a non-alternative voting, a single bloc of "communists and non-parties" was to be nominated.

The constitution of the state of the whole people preserved traditionally the Soviet approach to the ratio of collective and individual. It was mostly collectivist in nature and set the interests of the state and society above the interests of the individual ${ }^{44}$. The constitutional civil and political rights and freedoms, broadly enshrined in the constitutional text, did not have a detailed mechanism of guarantees both at the legislative level and at the level of judicial protection.

After August 1991, the collapse of the USSR was inevitable, leading to the cessation of the 1977 Constitution of the USSR, with changes and additions. Granting the status of a sovereign state to Ukraine has transformed the Constitution of the Ukrainian SSR in 1978 with amendments and additions from the constitution of one of the Union republics to the Basic Law of an independent state. This Constitution continued to

${ }^{44}$ В. Селіванов. Право і влада суверенної України: методологічні аспекти. Юридична думка. Київ 2002, р. 108. 
operate in the transitional period from 1990 to 1996 with changes in the political struggle of reform forces and forces that sought to revive the Soviet political system. Adopted for a monolithic society in the conditions of the political hegemony of the ruling party, this constitution was not clearly adapted to appease political conflicts by legal means. The changes reflected the multidisciplinary aspirations of various political forces. The Constitution failed to put an end to the confrontation between the legislative and executive powers, unable to withstand a change in the balance of political forces and rising socio-political tension.

The 1996 Constitution of Ukraine has a fundamentally different nature, related to new socio-political realities. The nature of the 1996 Constitution was largely determined by the political events that took place during its elaboration and on the eve of its adoption. However, the transformations that took place after 1996 in various fields of social and public life, a certain period of validity of constitutional norms indicate a gradual change of socio-political content of the Constitution of Ukraine ${ }^{45}$.

That is why today the constitutional process in Ukraine is gaining momentum and, at the same speed, concerns grow in circles of lawyers about the consequences of the adoption of the Basic Law. On the one hand, everyone understands that the Constitution of 1996 initially contained in its text a lot of inaccuracies, contradictions, insubordination, and references to laws that have not yet been adopted, and their fate is covered with the darkness of ignorance. This was accompanied by changes adopted under the influence of the political moment at the end of 2004. On the other hand, there is an extremely dangerous tendency to politicize the process of drafting and adopting the Constitution. Instead of lawyers and legal scholars, politicians and political consultants try to deal with this matter. As a result, there is a deadlock situation. The current Constitution does not quite satisfy the society, and this is bad, but another option may be even worse. In fact, the ongoing political struggle, which is barely covered by legal clothing, takes place against the backdrop of too low informing the society about its essence and the problems of the constitutional process.

\section{CONCLUSIONS}

Consequently, the main and still unresolved issue is the ambiguity of what is proposed to adopt: a new Constitution, a new version of the current Constitution, amendments and additions to the current Constitution. Although paradoxical, but in Presidential speeches, these terms are used

${ }^{45}$ В. Селіванов. Право і влада суверенної Украӥни: методологічні аспекти. Юридична думка. Київ 2002, р. 109. 
repeatedly as synonyms. However, legally they are completely different concepts. This terminological confusion carries a great danger of loss of landmarks and prevents a clear statement of the problem in a purely legal area.

Thus, we believe that the constitutional process is too politicized today. In our opinion, the acutest political struggle is underway for adopting a form of constitution that is convenient for one of the parties. But in fact for power - everyone wants a maximum of power. Including through their Constitution enforced in some way. However, the Basic Law should be adopted not from the conjuncture considerations of political expediency, but be a complete legal document, taking into account the achievements of the world jurisprudence, with the strict observance of all the prescribed legal procedures. After all, the constitution should be the main document of the state, at least for a decade.

\section{SUMMARY}

The scientific publication is devoted to highlighting the peculiarities of the legal nature of the constitution. The authors consider the structure and content of the constitution of the state in the context of its functions. The specificity of the content of the newest constitutions in the history of world constitutionalism is considered. The correlation between the constitution and the state policy is established. Modern approaches to understanding the nature of the constitution are considered. The legal nature of the Constitution of Ukraine is determined.

\section{REFERENCES}

1. Bielov, Dmytro M. 2010. "Struktura ta zmist konstitucii: okremi aspekti.” Naukovijj visnik Uzhgorodskogo nacionalnogo universitetu. Seria Pravo 14(1):80-87.

2. Chyrkin, B.E. 1999. Ob obekte konstitucionno-pravovogo regulirovanija. Rossijjskijj konstitucionalizm: problemy i reshenija: materiały mezhudunarodnojj konferencii. Moskva: Akademija.

3. Cippelius, Rajjngold. 2000. Filosofija prava. Kiev: Tandem.

4. Eremenko, Yurij P. 1982. Sovetskaja Konstitucija i zakonnst. Saratov: Izd-vo SGU.

5. Farberov, N. P. 1979. "Novaja Konstitucija SSSR - manifest ehpokhi stroitelstva kommunizma." In N.P. Farberov, Konstitucija razvitogo socializma, 67-81. Moskva: Voskhod-A.

6. Galkin, Aleksandr A., and Yurij Krasin. 1995. Rossija na perepute: avtoritarizm i demokratija: varianty razvitija. Juridicheskaja literatura.

7. Gladunjak, Ivan. 2007. "Konstitucija jak osnova fotmuvannja ta realizacii derzhavnoi politiki.” Viche 21-22:11-12. 
8. Khejjvud, Eh. 2005. Politologija. Moskva: Juniti-Dana.

9. Koliushko Igor, and Yurij Kirichenko. 2001. "Problemi dievosti Konstitucii Ukrajini ta udoskonalennja ii zmistu”. Parlament 3:12-15.

10. Kozlova, Ekaterina I., and Oleg Kutafin. 2003. Konstitutsionnoe pravo Rossii. Moskva: Jurist.

11. Kravec, Igor A. 2003. "Suchhnost konstitucijj i konstitucionnyjj process (dinamika socialno-politicheskogo soderzhanija rossijjskikh konstitucijj)”. Vesnik Moskovskogo 4:34-39.

12. Kresinoi, Irina O. (edited by). 2006. Politika, pravo i vlada $v$ konteksti transformacijjnikh procesiv $v$ Ukraini. Kiev: Institut derzhavi i prava im. V.M. Koreckogo NAN Ukraini.

13. Lenin, Vladimir I. 1980. Polnoe sobranie sochinenijj. Vol. XXXVI. Moskva: Politizdat.

14. Luchin, Viktor O. 1997. Konstitucionnye normy i pravootnoshenija: uchebnoe posobie [dla vuzov]. Moskva: Ehksmo.

15.Luchin, Viktor O. 2002. Konstitutsiya Rossijskoj Federatsii. Problemy realizatsii. Moskva: Juniti-Dana.

16. Lukjanova, Elena A. 2001. "Znachenie Konstitucii SSSR 1977 g. v razvitii istochnikov rossijjskogo gosudarstvennogo prava.” Gosudarstvo i pravo 4:22-27.

17. Marks, Karol, and Fridrich Engels. 1991. Sochinenija. Vol. I. Moskva: Politizdat.

18. Onishhenko, Olga V. 2005. Konstitucija Ukraini jak osnovne dzherelo konstitucijjnogo prava Ukraini. Kiev: Konsum.

19. Opryshko, Vitalijj F. 2000. Konstitucija Ukraini - osnova sistemi nacionalnogo zakonodavstva. Kiev: Vidavnichijj Dim «Juridichna Kniga».

20. Prieshkina, Olga V. 2009. Konstitucijjnijj lad Ukraini ta jogo rol u stanovlenni ta rozkvitu miscevogo samovrjaduvannja. Kiev: Institut zakonodavstva Verkhovnoi Radi Ukraini.

21.Redlich, Norman, Bernard Schwartz, and John Attanasio. 1995. Understanding Constitutional Law. Irwin: Matthew Bender.

22. Reiman, Jeffrey. 1988. "The Constitution, Rights, the Conditions of Legitimacy.” In Constitutionalism: The Philosophical Dimension, edited by Alan S. Rosenbaum, 132-139. New York: Greenwood Press.

23.Sajó, András. 1999. Limiting Government. An Introduction to Constitutionalism, Budapest: Central European University Press.

24. Salygin, Evgenijj N. 1999. Teokraticheskoe gosudarstvo. Moskva: Juridicheskaja literatura.

25. Savchyn, Michael B. 2009. Konstitucionalizm i priroda konstitucii. Monografija. Uzhgorod: Poligrafcentr «Lira». 
26. Selivanov, Volodimir. 2002. Pravo i vlada suverennoi Ukraini: metodologichni aspekti. Kiev: Juridichna dumka.

27. Shapoval V. M. 1997. Konstituciyne pravo zarubizhnih krayin: Pidruchnik. Kiev: ArtEk Vishha shk.

28. Shapoval, Vladimir. 2008. "Fenomen konstitutsii v kontekste otechestvennoy politiko-pravovoy «mifilologii»." Zerkalo nedeli 9 August, 29:4.

29. Shevchuk, Stanislav. 2002. Osnovi konstitucijjnoi jurisprudencii. Navch. posibnik. Kharkiv: Konsum.

30. Sjukijajjnen, Leonid R. 1986. Musulmanskoe pravo: voprosy teorii $i$ praktiki. Moskva: Nauka.

31.Sjukijajjnen, Leonid R. 1997. Shariat i musulmansko-pravovaja kultura. Moskva: Armada.

32. Stecjuk, Petro B. 2004. Osnovy teorii konstytucji ta konstytucjonalizmu. Chastyna persha: posibnyk dlja studentiv. Lviv: Astroljabija.

33. Stepanov, Igor M. 1984. Konstitucija i politika. Moskva: Izd-vo Nauka.

34. Stuchka, Petr I. 1929. "Dvenadcat let revoljucii gosudarstva i prava.” Revoljucija prava 6:56-61.

35. Todyka, Yurij N. 2000. Konstitucija Ukrainy: problemy teorii i praktiki. Kharkiv: Fakt.

36. Tyhomyrov, Yurij A., and I. V. Kotelevskaya. 1999. Pravovye akty: uchebnoprakticheskoe i spravochnoe posobie. Moskva: Jurinformcentr.

37. Yudin, Yurij L. 1987. "Konstitucii." In Konstitucionnoe pravo razvivajushhikhsja stran: predmet, nauka, istochniki, edited by Veniamin E. Chirkin, 38-42. Moskva: Juridicheskaja literatura.

\section{Information about the authors: \\ Bielov D. M.,}

Doctor of Law, Professor, Department of Constitutional Law and Comparative Law,

Uzhhorod National University

4, Narodna Sq., Uzghhorod, 88000, Ukraine

Vikhliaiev M. Yu.,

Doctor of Law, Professor, Department of Administrative, Financial and Informative Law,

Uzhhorod National University 4, Narodna Sq., Uzghhorod, 88000, Ukraine 